\section{Intersections}

Canadian Journal of Music

Revue canadienne de musique
Intersections CANADIAN JOURAL OF MUSIC
REVUE CANADIENEE DE MUSIOUH

\title{
The Long and Narrow Road: An Inuit Student's Journey Through Post-Secondary Music
}

\section{Kendra Jacque et Ellen Waterman}

Volume 39, numéro 1, 2019

Decolonizing Music Pedagogies

URI : https://id.erudit.org/iderudit/1075346ar

DOI : https://doi.org/10.7202/1075346ar

Aller au sommaire du numéro

Éditeur(s)

Canadian University Music Society / Société de musique des universités canadiennes

ISSN

1918-512X (numérique)

Découvrir la revue

Citer cet article

Jacque, K. \& Waterman, E. (2019). The Long and Narrow Road: An Inuit Student’s Journey Through Post-Secondary Music. Intersections, 39(1), 123-136. https://doi.org/10.7202/1075346ar
Résumé de l'article

L'eurocentrisme est profondément ancré dans les structures gouvernant la musique au postsecondaire, de l'admission au programme de formation. Dans cet article, une étudiante inuite du nord-est du Labrador relate son expérience à l'école de musique : les défis à accéder à une formation musicale et à naviguer les auditions, l'appui considérable de ses mentors et d'organismes de soutien, ainsi que le choc culturel, l'isolement et les micro-agressions raciales qu'elle a éprouvées à l'université. Plusieurs études qualitatives récentes au sujet des expériences universitaires d'étudiant-e-s autochtones fournissent le contexte de notre réflexion et vont dans le même sens que notre conclusion; à savoir que la décolonisation de la musique au postsecondaire doit s'appuyer sur un profond changement structurel et des cheminements plus flexibles pour les étudiants de même que des programmes de formation qui répondent aux besoins d'une société plurielle. (c) Canadian University Music Society / Société de musique des universités canadiennes, 2021
Ce document est protégé par la loi sur le droit d'auteur. L'utilisation des services d’Érudit (y compris la reproduction) est assujettie à sa politique d'utilisation que vous pouvez consulter en ligne.

https://apropos.erudit.org/fr/usagers/politique-dutilisation/ 


\title{
THE LONG AND NARROW ROAD: AN INUIT STUDENT'S JOURNEY THROUGH POST- SECONDARY MUSIC
}

\author{
Kendra Jacque and Ellen Waterman
}

\section{INTRODUCTION}

By now it has become clear that post-secondary music is trapped in an outmoded, Eurocentric model that is not adequate to the needs of a diverse student population living in a pluralistic society. ${ }^{1}$ Calls for structural reform of post-secondary music are gaining increasing traction in the twenty-first century, as evidenced by several panels on curricular reform and decolonization of music studies hosted by the Canadian University Music Society and the Canadian Society for Traditional Music, and the College Music Society's Report of the Task Force on the Undergraduate Music Major (Shehan Campbell et al. 2014). ${ }^{2}$ In 2017, Harvard University's Department of Music removed the traditional mandatory core curriculum from its music degree to better reflect the diversity of its students and faculty, a step perhaps more easily taken in a liberal arts environment than in the traditional conservatory-style bachelor of music.

Streaming students towards a Eurocentric approach to music, however, starts long before university. The portal through which students enter the BMus is typically small and constricting: the price of admission is considerable musical literacy (most often in classical music or jazz) and presumed familiarity with a lexicon of related terms and techniques. Even though many of us know from

1 We use the word "Eurocentric" deliberately to point to the foundations upon which North American post-secondary music programs were built and that still largely structure entrance criteria, curricula, and assessment despite the growth of jazz, popular music, and ethnomusicology programs that have been grafted onto this structure. As several scholars have argued, for example, the institutionalization of jazz has often resulted in an uneasy negotiation between its roots in oral African American tradition and improvisation and the requirement to submit to WAM values such as literacy, the primacy of the work, and standardized performance practice. (See Ake 2002; Murphy 2009; Walker 2020; Wilf 2014).

2 Roundtable: Anna Hoefnagels, Heidi Aklaseaq Senungetuk, Gillian Turnbull, Margaret Walker, and Louise Wrazen, "Rethinking Priorities in Post-secondary Music Curricula Today: Decolonizing, 'Indigenizing,' and Visions for the Future," Canadian Society for Traditional Music, University de Québec à Montréal, 25 May 2019; Standing Committee of Institutional Members brown bag lunch panel: Dylan Robinson, Margaret Walker, Rex Smallboy, Mary Ingraham, and Ellen Waterman, "Decolonization and Action," Canadian University Music Society, University of British Columbia, 7 June 2019. 
experience that students entering university music programs seldom match this profile, it remains the gold standard. The system, which accommodates only certain instruments and vocal styles, privileges students with means and access to instruments, music lessons, and ensemble playing. Eurocentrism is deeply embedded in our structures as well as our curricula.

This article focuses on the specific context of the Canadian Bachelor of Music degree. ${ }^{3}$ Although the restrictions described above are problematic for many students living in small or remote communities or with limited economic means, it is arguable that access to the Bachelor of Music program poses particular challenges for Indigenous students, who are already marginalized in Canadian universities (Gallop and Bastien 2016; Rodon et al. 2014). ${ }^{4}$ In this article, we (Kendra Jacque, an Inuit music student from the northeast coast of Labrador, and Ellen Waterman, a white settler-Canadian ethnomusicology professor and former music dean) draw on a series of dialogues to tell the story of one Inuit student's journey into and through post-secondary music education. This "ethnography of the particular" (Abu-Lughod 2009) supports the findings of other qualitative studies about the experiences of Indigenous university students (Bailey 2016; Clark et al. 2014; Godlewska, Schaefli, Freake et al. 2017; Godlewska, Schaefli, Massey et al. 2017; Indspire 2018; Schaefli et al. 2018), but within the particular context of music.

\section{Decolonization and Ethnographies of the Particular}

Education theorist Marie Battiste (Mi'kmaq) puts critical pressure on universities' indigenization efforts that too often fail to "interrogate the existing cultural interpretative monopoly of Eurocentric knowledges, assumptions, and methodologies." She insists that we need to move beyond "mere 'culture' discourses" that operate as "othering strateg[ies]" $(2013,103)$ by positing cultural difference as homogeneous and static. This article adopts a strategy for "writing against culture" first outlined by feminist anthropologist Lila Abu-Lughod, who advocates for "ethnographies of the particular"-telling the detailed stories of individual people's experiences-as a means of highlighting positionality. As she notes, "The effects of extralocal and long-term processes are only manifested locally and specifically, produced in the actions of individuals living their particular lives, inscribed in their bodies and their words" $(2009,160)$. In recounting Kendra's story, we resist the trope of exceptionalism and situate Kendra's experience within the larger aspirations and struggles of music students and Indigenous students in general. As Kendra frequently stated, "I don't

3 For a useful comparison see, for example, "Action, Criticism, \& Theory for Music Education," guest editor Guillermo Rosabal-Coto, special issue, ACT / Action for Change in Music Education 18, no. 3 (2019), http://act.maydaygroup.org/volume-18-issue-3/, which provides perspectives on decolonization of music education and music studies from the Southern Hemisphere.

4 Following Godlewska, Schaefli, Massey et al. (2017), in this article we use the term "Indigenous" to refer broadly to all First Nations, Inuit, and Métis people in Canada, and the word "Aboriginal" when referring specifically to Newfoundland and Labrador. "The attachment to the term 'Aboriginal' in Newfoundland and Labrador derives from the decades long fight, since Confederation (1949), by the Indigenous peoples of the province for recognition as Aboriginal peoples" (580). 
want my experience to take away from anyone else's." But her story does reflect her determination to take her space in the musical world.

Not only is "every act of speaking a speaking from somewhere" (AbuLughod 2009, 155), but listening too is an act of critical positionality (Robinson 2020, 9-11). Accordingly, our methodology is dialogical, and it reflects the different perspectives of our life experience, age, and ethnicity. We began by signing a letter of agreement that acknowledged the power dynamic between professor and student and clearly outlined Kendra's rights (including the right to withdraw from the project at any time). Between December 2018 and March 2019, we engaged in four extended conversations, which we recorded and loosely transcribed. We then read and discussed the transcriptions and decided on a format for the article. We shared and commented on each other's draft writing and edits. Kendra organized and wrote her story by referring to the transcriptions and the original recordings, and Ellen examined the secondary literature to situate Kendra's experience within the larger project of understanding Indigenous students' experiences of post-secondary education. We conclude by offering some strategies to improve the diversity of, and access to, post-secondary music in Canada.

\section{KENDRA's STORY}

\section{Kendra Jacque}

My name is Kendra and I am an Inuk from Makkovik, a small fishing port of 360 people on the northeast coast of Labrador. The majority of my life has been spent there, apart from leaving for post-secondary studies. I am going into my fourth year in the Conjoint Bachelor of Music/Music Education program at Memorial University of Newfoundland (MUN) in St. John's. 5 My journey into music school was quite different from an urban music student because I had to take lessons via Skype and to advance musically in a community that had little to no resources for learning music. John Christian Erhardt Memorial School in Makkovik provides education for grades K-12. I really enjoyed my time in school, and from a young age I knew I wanted to be a teacher. Makkovik is an isolated community, so having access to Western music education was quite rare. There was a small window of opportunity from 2006 to 2009 when the school had a Western-trained music specialist who was a recent graduate from MUN, and looking back, I was extremely lucky to have music teachers in grades 9 to 12 who supported my endeavours. It's also worth stating that Inuit traditional music was not available to me at this time. Inuit traditional music was introduced to the curriculum only when I was in the middle of grade 12 in 2009 and was taught for a few years after. Much of the training during my time in high school consisted of Newfoundland folk tunes, and I did not study classical music until preparing my auditions for university.

Most of the people who live in Makkovik are Inuit. My family, among many others in town, live off of the land, go berry picking, and fish during

5 At the time of writing, summer 2019. 
the summers. The winters are incredibly long and harsh, with an abundance of snow each year. The snow usually stays until spring, so we are on snowmobiles for nearly six months of the year. Growing up in such an isolated area, I thought living this kind of life was normal for everybody.

The seasons are quite different in northern Labrador, compared to St. John's. "Spring" for me means that we can be on our snowmobiles without a jacket! The days are warmer, but there is just as much snow as there is in the winter. Fall is a brief period when school starts again, and the first snowfall usually happens in late October or early November (although the snow does not stay until mid-December). Summer is notorious for blackflies and humidity. The winters are known for snow days and shovels!

I grew up in a musical family. My dad played in a band before I was born, and my brother was a multi-instrumentalist. The violin is my main instrument. We had a family band that played in my cousin's shed and at the hall in Makkovik. No matter how hard I tried, I could not get my brother to play the violin! I believe he thought that instrument was unique to me and did not want to take it away. He played classic rock and had the set-up for an entire rock band, including electric guitars, drums, and amplifiers. My mother does not play any instruments, but I always made the joke that a family band needs an audience!

I remember playing the recorder in grade school, probably back in grades 2 and 3 . I don't remember exactly what the lessons consisted of, but they were short-lived. Music was not in the curriculum until I was introduced to the violin at the end of grade 9. The principal wanted more arts in the curriculum and flew in a whole set-up to create a music class: ten violins and the materials required to teach it. We learned for about a month before ending for the summer break. Music spoke to me in so many ways: there was a new creative outlet and it developed my time-management and organizational skills. For the next three years music was still in the curriculum, offered as an elective. My class had eight students, and by grade 11 we were all near the same skill level.

Music classes were funded through the Nunatsiavut government in grades 10 and 11, and the classes thrived. The students enjoyed the classes more, and during these two years we were taught by Rebecca Pretty, a recent graduate from my current program in music/music education at MUN. In those years, we had a traditional Newfoundland and Labrador fiddle group with three players who would play after classes, and we got to travel to perform. We played at the Rotary Festival in St. John's and the Lake Melville Music Festival in Goose Bay in grade 12 with our new music teacher, Natalie Jacque (no relation).

In grade 12, music was optional, and many of my classmates chose not to take the class. By this time, I knew I wanted to do something musical in post-secondary studies but had no idea how to go about things. The school was extremely supportive of my endeavours, and I got to do two music classes and two math classes in my final year. I did applied music with Miss Jacque (I was the only student, so it was the equivalent of private violin lessons) and the other 
class was an online course run by the province. This class was called "Experiencing Music" and the students studied the tin whistle. ${ }^{6}$

That summer in 2008, I had the opportunity to play some music at the Moravian Music Camp in Hopedale. Moravian missionaries came to northern Labrador in the late eighteenth century, and an Inuit tradition of Moravian brass, string, and choral music is still active in Nain, Hopedale, and Makkovik. At camp, I met Dr. Tom Gordon for the first time; at that point he was director of the School of Music at MUN. He encouraged me to pursue music school, but I had no idea what the application process was like. I ended up taking a year off after high school and applied to college in Goose Bay the following year. My music-making at this point came to a halt.

After completing college in 2011, I was back in Makkovik wanting to take lessons again. As part of his research on Inuit Moravian church music, Dr. Gordon brought the Innismara Choir and some brass and string musicians from St. John's to work with local musicians. Seeing all of the musicians perform gave me a greater idea of what it would be like to have a career as a professional, but I had a long road ahead of me. I took violin lessons for approximately five years before getting accepted into music school, starting in 2011 via Skype. Through a Google search I found a person in the United States and we did lessons together for about a year. The man was Russian and had a strict classical upbringing, which was evident in our lessons. We studied Suzuki book 2, and this was around the time my fundamentals were taught. The teacher emphasized the importance of a metronome but did not explain very well how to actually use it (for some reason I associated the clicks as quarter notes, but in reality, the clicks are arbitrary). We ended lessons in early 2012, unfortunately on a sour note. I was working on the final piece in Suzuki book 2 and there was an odd syncopation I could not grasp for weeks on end. The teacher ended the final lesson with "You're not cut out to make music." I was more discouraged than ever and did not pursue lessons until late summer. I then took lessons with another American, but this was also short-lived.

In fall 2012, I attended MUN in St. John's for the first time. I enrolled in four classes, all of which were music classes open to non-majors. It was not until this time that I learned about the audition process. The requirements for auditioning as a violinist at MUN are substantial; the auditionee needs years of experience to be considered because the studio is so strong. I experienced culture shock for the first time but did my best in school. I took violin lessons in person with a fourth-year student named Maggie Burton, whom I had met in Makkovik with Dr. Gordon. This was my first time having lessons in person with an advanced violin teacher, and Maggie did a great job filling in the gaps in my musical training. We took about two months relearning the correct bow hold, and it was my first time studying higher-level classical music. I went from traditional Newfoundland and Labrador folk tunes to Bach's D minor

6 Acknowledging its relative isolation, large landmass, and small population, the province of Newfoundland and Labrador was an early adopter of distance learning technologies. Interactive music classes are provided by the Centre for Distance Learning and Innovation online via internet-based learning platforms and a province-wide Polycom video networking system. 
Partita. The transitions were abrupt and intimidating, but somehow we made it all work. We also studied all the scales and arpeggios for violin along with etudes. This all occurred within three months, and there was plenty of material to cover and review each day. Near the middle of November, I was told that my brother was ill and had to be sent to St. John's for treatment. He passed away shortly after. My brother was a musician as well, and we were inseparable. Losing him felt like I lost a part of myself.

I resumed lessons in the fall of 2013, this time from Makkovik via Skype. I studied with Lauren Smee, a master's student in violin performance and pedagogy at MUN. We studied together for about a year and a half, and she helped me prepare for my first audition in the winter of 2015. The lessons were paid for by a gift to the School of Music from the Sisters of Mercy of Newfoundland, a congregation of nuns who support the arts. Dr. Gordon had informed me that there was funding available through the International Grenfell Association to pay for my travel to the audition, so I was able to attend in person. I played pieces by Bach and Handel. Both were unaccompanied because there was no one in Makkovik to play with me, and it would have been too short notice for an accompanist to play with me in St. John's. After a long wait, in May I was told I needed more lessons and should try again in another year. I was crushed. Again. But with continued support from the School of Music I started lessons with my current teacher, Jennifer Johnson, in the fall of 2015 via Skype again. This time the audition took place in Makkovik via the school's Polycom video conference system. To my surprise, this audition was successful! I received my acceptance letter just a few weeks later.

This was just the beginning! Now I actually had to pack up and leave for St. John's again. There were so many opportunities to look forward to as a budding violinist at the School of Music: playing with the youth orchestra ${ }^{7}$ and the MUN Chamber Orchestra, singing in the school choirs, and playing in master classes. I was beginning a whole new journey to becoming a professional violinist.

I started music school in the fall of 2016 and have received a lot of support throughout my degree. Upon my acceptance, I was the inaugural recipient of the Aboriginal Music Award, a scholarship organized by a former Indigenous music student named Mitchell Fleming. In my second year I was awarded the opportunity to play the Grenfell violin, one of several high-quality string instruments that the school makes available to students. The violin was made in 2017 by St. John's luthier Rodney de Vries and is valued at \$10,0oo. In my second and third years, I was awarded scholarships through Indspire, an Indigenous company that provides financial support for Indigenous students. I am also sponsored by the Nunatsiavut Government through the Post-Secondary Student Support Program (PSSSP); they cover my tuition, living allowance, and

7 The CALOS Youth Orchestra (formerly the Newfoundland Symphony Youth Orchestra) primarily serves junior and senior high music students in St. John's but has a close relationship with the MUN School of Music. See CALOS, Youth Orchestras, https://calosmusic.ca/. 
travel home. To travel from Makkovik to St. John's return costs approximately $\$ 1500$.

As a late bloomer pursuing a career in violin, I had to overcome many hurdles to get to where I am today, and I have received a lot of support. However, as a minority Aboriginal student I have also struggled to feel accepted in university. Very few fellow students in music school identify as Aboriginal, and people sometimes make ignorant assumptions about Inuit culture. I did not experience overt external racism until my third year of music school. This was the first time I was called a "gas sniffer," and it came completely out of left field. I was shocked but took this as a teaching opportunity and informed that person that not all people in Labrador have that problem. Some of my friends have also dealt with internalized racism, where other Inuit think they are not authentic; for example, because of a pale complexion. I'm also a bit shy about expressing my current interest in traditional Inuit music at home because this was not part of my childhood and I don't want to seem "trendy."

When I first started school at MUN, I realized that Aboriginal people are definitely a minority at the university. I saw this as an opportunity to educate my peers and colleagues about what it is like to be Inuit. In my second year of music school, I embraced my Inuit identity. I proudly stated who I was, but after a few months the tale got old fast. I heard comments such as "We know about who you are," and "Yes, you mentioned that to us before." It felt as if I were a broken record but still wanted to get my point across. I began to spend a lot more time at the Aboriginal Resource Office (ARO) at MUN. The students and staff there are always welcoming, and I feel more comfortable there than hanging out at the student lounge in the music school.

As my third year began, I realized that I was a lot more than an Inuit person. Although I am proud of this, it is one part of who I am. I am also a video gamer and a metalhead! Although I am still involved with the ARO, I tried with some success to branch out as an individual this year. I started to embrace the teacher side of myself and get in touch with who I envisioned myself being as a teenager. The music education program at MUN is tailored to my career aspirations, and my big goal is to go back home to Makkovik and teach.

During our first discussion on this topic, Ellen asked me how we can decolonize music schools across Canada. I had no idea how to answer this question! Upon discussing this for quite some time, we came to the conclusion that there is no one right answer, but myriad smaller answers create a fuller solution. Initially, I felt that the decolonization of universities was just a Band-Aid for something that required surgery. We are definitely going in the right direction, but I do also believe we do not know where we are headed. I believe we still need to ask, What is the ultimate goal of decolonizing the university?

\section{Situating Kendra's Experience}

\section{Ellen Waterman}

In this section, I situate Kendra's story within the broader literature on Indigenous post-secondary education and studies of Indigenous students' experience 
at Memorial University in particular. I then outline some steps that could be taken towards decolonizing post-secondary music in Canada, including local, individual initiatives and larger, structural changes. Kendra's provocative question about our ultimate goal in decolonizing the university calls us to account for our motives and our actions; it invites us to seriously rethink the structures and purpose of post-secondary music education in Canada.

Recent qualitative studies of Indigenous students' university experiences reveal striking parallels with Kendra’s story. Godlewska, Schaefli, Freake et al. (2017) and Godlewska, Schaefli, Massey et al. (2017) conducted surveys and interviews with Aboriginal and non-Aboriginal students who entered MUN in 2013. ${ }^{8}$ They found that the majority of students had little knowledge of the diversity of Aboriginal peoples in Newfoundland and Labrador, which includes Mi'kmaq, Innu, and Qalipu First Nations and the Nunatsiavummiut and NunatuKavummiut (Godlewska, Schaefli, Massey et al. 2017, 584).9 Indeed, Kendra reported having the same knowledge deficit before her involvement with the ARO, and she lamented the fact that her high school social studies curriculum focused primarily on Newfoundland with little Labrador content. ${ }^{10}$ Tellingly, when asked about their knowledge of Aboriginal culture, only 15.5 per cent of survey respondents correctly answered questions about Aboriginal musicians (585). In our conversations, Kendra and I discussed my inclusion of Inuit content in a twentieth-century music course. Kendra appreciated the content but expressed her disappointment at the poor class attendance for this unit. Godlewska et al. also documented misconceptions about funding: a significant percentage of students assumed that all Aboriginal students were getting a "free ride" from the government (585). Although Kendra is sponsored by Nunatsiavut, PSSSP comes with a heavy administrative burden and rules that do not always mesh with MUN's systems. She also bears the high economic cost and emotional stress of living far away from home. Clearly, mere inclusion is insufficient. Universities need to cultivate deeper knowledge and understanding of Indigenous peoples and cultures (Gaudry and Lorenz 2018). Music programs need to (1) address basic misunderstandings about Indigenous culture and cultivate more empathy for the challenges Indigenous students face, and (2) think about how the foundation on which university music programs are built can and should be changed. ${ }^{11}$

Another parallel theme is racial micro-aggression, "brief and commonplace verbal, behavioral, and environmental indignities with detrimental cumulative psychological effects on people of color" that are often subtle and even

8 See also their previous survey of Indigenous students at Queen's University (Godlewska et al. 2013), which was followed up by a study of ten universities in Ontario (Schaefli et al. 2018).

9 The Nunatsiavummiut are the Inuit people of northern Labrador, and the NunatuKavummiut are of mixed Inuit and European heritage, living in south to central Labrador.

10 Godlewska, Schaefli, Freake et al. note that although there has been some curriculum reform, particularly in grades 7 and 9, as of 2017 the Newfoundland and Labrador school curricula still contained erroneous and inconsistent information. The 2013 cohort would not have benefitted from recent improvements $(2017,582)$.

11 For an encouraging online resource in the U.S. context, see "Decolonizing the Music Room," https://decolonizingthemusicroom.com. 
unintentional but are nonetheless harmful (Clark et al. 2014, 113). A qualitative study of Indigenous students at McMaster University (Bailey 2016) revealed both reluctance among Indigenous students to self-identify (1268) and experiences of in-class racism (1269). Similarly, students interviewed by Clark et al. identify micro-insults (encountering expectations of primitiveness), micro-invalidation (enduring unconstrained voyeurism, withstanding jealous accusations, experiencing curricular elimination or misrepresentation), and environmental micro-aggression (living with day-to-day cultural and social isolation) $(2014,117-20) .{ }^{12}$

Like Kendra, many Indigenous students emphasize the importance of safe and supportive spaces like the ARO (Gallop and Bastien 2016; Indspire 2018). Kendra notes her acute discomfort in the student music lounge, a space where she would not be comfortable identifying as Inuit. Busy music students juggling classes, lessons, and ensembles tend to spend long hours in the music building. At MUN, the lounge is a haven to some students, while others call it "the place work goes to die." Kendra was fortunate to find a home at the ARO, but it is telling that she had to leave the Music building to be comfortable at MUN.

Nevertheless, Kendra's joy in her music studies and pride in her developing skills were the dominant themes in our dialogues. She often acknowledged her supportive family and faculty mentors and called her music education colleagues a "great crowd." She noted her excitement at finding her groove in the university chamber orchestra and in assisting with Dr. Gordon's Moravian music research. She is full of ideas about tailoring music education for children in Makkovik. Most important to Kendra's success, however, is her self-determination, resilience, and passion for her chosen course of study. These qualities mirror the elements of success identified in the literature (Gallop and Bastien 2016, 209-11). But it has, indeed, been a long road. Kendra will be thirty-one when she graduates.

In a study of post-secondary education in Inuit Nunangat, Rodon et al. (2014) point to the importance of college transfer programs such as the one Kendra attended in Labrador, but they also address the difficulty northern Inuit have in accessing post-secondary programs, especially ones that address Inuit culture and needs (71). As they note, "For Inuit students, post-secondary education is often an all-encompassing experience that profoundly alters their way of life by removing them from their home communities. For this reason, they often need more support than average Southern students" (72). The School of Music at MUN took extraordinary steps to find (and fund) creative solutions to Kendra's challenges of distance, isolation, and need for a good instrument so that she could succeed within the current system. MUN has implemented individual-focused strategies with some success, but further research needs to be done to understand how to undertake the kinds of structural changes that support indigenization as decolonization in music programs.

12 For another good source on racism in the classroom see Cote-Meeks (2014). 
Clearly, there is no "one size fits all" solution to decolonizing and diversifying post-secondary music. Kendra mentioned the need for many small changes, and here I suggest some of these-as well as some deeper and more challenging structural changes. In compiling the following list, I am inspired and informed by my conversations with Kendra, and also by two recent panels, at the Canadian Society for Traditional Music and the Canadian University Music Society conferences in 2019. The recommendations below are informed by Kendra's and my recent experience; they are widely applicable and already somewhat in practice. Strategies for decolonization will vary according to the size, structure, and resources of particular music programs, and the needs of local Indigenous cultures in all their diversity. Some can be implemented by individuals; others will require significant institutional resources and united effort of Canadian music programs.

1. Build relationships with Indigenous communities. We can take the time to get to know Indigenous people in our communities and invite elders and culture bearers to our classes, following local protocols and offering respectful compensation. ${ }^{13}$

2. Hold space for Indigenous artists. In 2018, the MUN School of Music received a grant to launch a program of Indigenous artists-in-residence, including Inupiaq violinist and ethnomusicologist Heidi Aklaseaq Senungetuk. Such programs create wonderful opportunities for mutual learning and collaboration, as well as offering inspiring role models for students. What would it mean to move beyond the paradigm of concerts and master classes-to hold space for the resurgence of Indigenous artists? One exciting example is Dylan Robinson's (Stó:lō) and Candice Hopkins's (Tlingit) art/ music exhibition Soundings: An Exhibition in Five Parts, which brought Indigenous artists together with Indigenous and non-Indigenous musicians to reimagine the concept of the musical score in work that encompasses performance, ritual, gatherings, discussions, collaboration, and listening. ${ }^{14}$

3. Ask new questions. Revisit existing courses both to educate ourselves and our students about decolonization and to broaden the scope of music studies. For example, instead of centring the twentieth-century music history course upon the narrative of modernism and innovation, we could foreground themes of (de)colonization, migration, civil rights activism, and pluralism. Asking new questions will lead us to explore more diverse musical geographies, repertoires, communities, and practices that are either absent

13 Here I'm inspired by my colleague Anna Hoefnagels, ethnomusicologist and director of Indigenous and Canadian Studies at Carleton University, who described her relational pedagogy during the CSTM Roundtable 25 May 2019 (cited in note 2).

14 Soundings: An Exhibition in Five Parts was held at Agnes Etherington Art Gallery, Queen's University, Kingston, Ontario, from 5 January to 7 April 2019. The exhibition subsequently toured in the United States and Canada. https://agnes.queensu.ca/exhibition/soundings-an-exhibition-in-fiveparts/. 
from, or exist in the margins of, current curricula. To be sure, remodelling existing courses will not address structural issues, but it is nevertheless challenging and productive work that can foster openness, curiosity, and respect.

4. Develop more articulation agreements with college-level music programs to allow for cross-fertilization and sharing of resources, to provide more points of access to the BMus, and to strengthen the whole network of music studies across Canada.

5. In consultation and collaboration with Indigenous communities, develop culturally appropriate Indigenous music education curricula at the elementary and secondary school level as well as the post-secondary level. Indigenous faculty in Canadian universities are leaders in such curriculum development, but the burden of decolonization cannot be carried solely by a small number of Indigenous faculty who already carry a heavy load in championing university indigenization efforts. ${ }^{15}$ This material should be integrated into post-secondary music education programs along with other forms of diversity training.

6. Hire Indigenous music faculty, as recommended by researchers (e.g., Pete 2016; Gaudry and Lorenz 2018) and in line with many universities' indigenization policies. Take an open and innovative approach to doing so. We need to ask ourselves why fine arts programs have had more success with Indigenous hires than have music programs in Canada. ${ }^{16}$ Is the road to jobs in music departments also too long and narrow? As Dylan Robinson (2020) has argued compellingly, we need to embrace the idea that there are multiple ways of knowing and being in the world and hold space for the resurgence of Indigenous music and musicians.

7. Create inclusive spaces. We need to consider how our music facilities can be made more open and welcoming to all students, and we need to have clear policies about expected behaviour. A good start is Shauneen Pete's recommendation that deans should "create physical spaces that reflect Indigenous peoples' histories, contributions, languages and diversities. Review and develop signage, bulletin boards, and promotional materials for inclusion of diverse students, staff, and faculty" $(2016,83)$. Music programs could take Pete's suggestion to heart and ensure that their physical spaces reflect the diversity of their students.

15 For an excellent example of such a resource, see the Collaborative Indigenous Learning Bundles conceived by Kahente Horn-Miller at Carleton University and made available to all faculty with suggestions of how to integrate them into their classes. https://carleton.ca/edc/carleton-university-collaborative-indigenous-learning-bundles-cucilb/

16 See, for example, OCADU's bundled hiring of five Indigenous faculty in 2018: https://www2. ocadu.ca/news/ocad-university-hires-five-new-permanent-indigenous-faculty. To be sure, fine arts most often has the MFA as a terminal degree, but I would argue that the more salient point here is that fine arts as a discipline values difference and diversity of aesthetics and practice. 


\section{Concluding Thoughts}

Decolonization of the BMus will require a fundamental restructuring and diversification of music programs across Canada. This need not mean devaluing the rich tradition of Western art music, including applied music, but it does mean taking imaginative approaches to curriculum development and creating more diverse pathways in and through music studies. To do so means grappling with some hard questions. Why do we continue to accept the outdated notion of standardization with its narrow and prescriptive pathways? Whom is it serving, and whom does it exclude? What exciting new opportunities might open up if we embraced the idea of diversity across music programs in Canada? Kendra's story is a cautionary tale about the inaccessibility of post-secondary music education for many students. Canadian music programs exist in a challenging recruitment environment, competing for an ever-shrinking pool of qualified students, narrowly conceived. But what if our approach to recruitment is fundamentally flawed? What if the answer lies in radically reimagining music studies for a pluralistic world? What would happen if, instead of seeking out students who fit current program requirements, or identifying new markets to tap, we instead asked, "How can we make post-secondary music more equitable?" Or better, "How can we remove barriers to post-secondary music studies?" If we are serious about participating in the vital project of reconciliation with Indigenous peoples in Canada, and if we are truly committed to decolonizing music studies, university music programs need to pursue deep and thoughtful structural change. This change is long overdue.

\section{REFERENCES}

Abu-Lughod, Lila. 2009. "Writing against Culture." In Feminist Anthropology: A Reader, edited by Ellen Lewin, 152-69. New York: John Wiley \& Sons.

Ake, David. 2002. Jazz Cultures. Berkeley: University of California Press.

Bailey, Kerry A. 2016. "Racism within the Canadian University: Indigenous Students' Experiences." Ethnic and Racial Studies 39 (7): 1261-79.

Battiste, Marie. 2013. Decolonizing Education: Nourishing the Learning Spirit. Saskatoon: Purich, and Vancouver: University of British Columbia Press.

Clark, Anthony D., Sela Kleiman, Lisa B. Spanierman, Paige Isaac, and Gauthamie Poolokasingham. 2014. "'Do You Live in a Teepee?' Aboriginal Students' Experiences with Racial Microaggressions in Canada." Journal of Diversity in Higher Education 7 (2): 112-25.

Cote-Meeks, Sheila. 2014. Colonized Classrooms: Racism, Trauma and Resistance in Post-Secondary Education. Winnipeg: Fernwood.

Gallop, Cynthia J., and Nicole Bastien. 2016. "Supporting Success: Aboriginal Students in Higher Education." Canadian Journal of Higher Education / Revue canadienne d'enseignement supérieur 46 (2): 206-24.

Gaudry, Adam, and Danielle Lorenz. 2018. "Indigenization as Inclusion, Reconciliation, and Decolonization: Navigating the Different Visions for Indigenizing the Canadian Academy." AlterNative, An International Journal of Indigenous Studies 14 (3): 218-27. 
Godlewska, Anne, Jennifer Massey, Jones K. Adjei, and Jackie Moore. 2013. "The Unsustainable Nature of Ignorance: Measuring Knowledge to Effect Social Change. First Results of an On-line Survey of Aboriginal Knowledge at Queen's University." Canadian Journal of Native Studies 33 (1): 65-95.

Godlewska, Anne, Laura Schaefli, Sheila Freake, Jennifer Massey, and John Rose. 2017. "Awareness of Aboriginal Peoples in Newfoundland and Labrador: Memorial's First-Year Students 2013 Speak." Canadian Geographer / Le Géographe canadien 61 (4): 595-609.

Godlewska, Anne, Laura Schaefli, Jennifer Massey, Sheila Freake, Jones K. Adjei, John Rose, and Chloe Hudson. 2017. "What Do First-Year University Students in Newfoundland and Labrador Know about Aboriginal Peoples and Topics?" Canadian Geographer / Le Géographe canadien 61 (4): 579-94. Indspire. 2018 (September). "Post-Secondary Experience of Indigenous Students Following the Truth and Reconciliation Commission." Summary of Survey Findings. Indspire: Indigenous Education, Canada's Future.

Murphy, John P. 2009. "Beyond the Improvisation Class: Learning to Improvise in a University Jazz Program." In Musical Improvisation: Art, Education, Society, edited by Gabriel Solis and Bruno Nettl, 185-99. Urbana: University of Illinois Press.

Pete, Shauneen. 2016. "100 Ways: Indigenizing and Decolonizing Academic Programs.” Aboriginal Policy Studies 6 (1): 81-9.

Robinson, Dylan. 2020. Hungry Listening: Resonant Theory for Indigenous Sound Studies. Minneapolis: University of Minnesota Press.

Rodon, Thierry, Fiona Walton, Frances Abele, Sheena Kennedy Dalseg, Darlene O'Leary, and Francis Lévesque. 2014. "Post-Secondary Education in Inuit Nunangat: Learning from Past Experiences and Listening to Students' Voices." In "Revitalizing Education in Inuit Nunangat," special issue, Northern Public Affairs 2, 70-5.

Schaefli, Laura, Anne Godlewska, Lisa Korteweg, Andrew Coombs, Lindsay Morcom, and John Rose. 2018. "What Do First-Year University Students in Ontario, Canada, Know about First Nations, Métis, and Inuit Peoples and Topics?" Canadian Journal of Education / Revue canadienne de l'éducation 41 (3): 689-725.

Shehan Campbell, Patricia, David Myers, Ed Sarath, Juan Chattah, Lee Higgins, Victoria Levine, David Rudge, and Timothy Rice. 2014 (November). Transforming Music Study from Its Foundations: A Manifesto for Progressive Change in the Undergraduate Preparation of Music Majors. Report of the Task Force on the Undergraduate Music Major. College Music Society.

Walker, Margaret E. 2020. "Towards a Decolonized Music History Curriculum.” Journal of Music History Pedagogy 10 (1): 1-19.

Wilf, Eitan Y. 2014. School for Cool: The Academic Jazz Program and the Paradox of Institutionalized Creativity. Chicago: University of Chicago Press. 


\begin{abstract}
Eurocentrism is deeply embedded in the structures governing post-secondary music, from admissions to curricula. In this article, an Inuit student from northeastern Labrador recounts her journey to and through music school, including the challenges of accessing music instruction and navigating the audition, the considerable supports she received from mentors and organizations, and the culture shock, isolation, and racial micro-aggressions she experienced in university. Several recent qualitative studies of Indigenous students' university experiences provide context for and support our conclusion that decolonization of post-secondary music must include deep structural change to provide broader and more flexible pathways for students and curricula that respond to the needs of a pluralistic society.
\end{abstract}

\title{
RÉSUMÉ
}

L'eurocentrisme est profondément ancré dans les structures gouvernant la musique au postsecondaire, de l'admission au programme de formation. Dans cet article, une étudiante inuite du nord-est du Labrador relate son expérience à l'école de musique: les défis à accéder à une formation musicale et à naviguer les auditions, l'appui considérable de ses mentors et d'organismes de soutien, ainsi que le choc culturel, l'isolement et les micro-agressions raciales qu'elle a éprouvées à l'université. Plusieurs études qualitatives récentes au sujet des expériences universitaires d'étudiant-e-s autochtones fournissent le contexte de notre réflexion et vont dans le même sens que notre conclusion; à savoir que la décolonisation de la musique au postsecondaire doit s'appuyer sur un profond changement structurel et des cheminements plus flexibles pour les étudiants de même que des programmes de formation qui répondent aux besoins d'une société plurielle.

\section{BIOGRAPHIES}

Kendra Jacque is an Inuk from Makkovik, on the northeast coast of Labrador. She is a fourth-year student, specializing in violin, in the conjoint degree program in Music and Music Education, at Memorial University of Newfoundland in St. John's. Kendra is a research assistant for Dr. Tom Gordon's project on Inuit Moravian music. She aspires to be a teacher and take what she has learned at university back home upon completion of her studies.

Ellen Waterman is a settler-Canadian who grew up in rural Manitoba on Treaty One land. In 2019, she was appointed Helmut Kallmann Chair for Music in Canada at Carleton University. An ethnomusicologist and flutist specializing in improvisation and experimental music, she co-edited Negotiated Moments: Improvisation, Sound and Subjectivity (with Gillian Siddall, Duke 2016). Previously, Ellen taught at Memorial University of Newfoundland from 2010 to 2018, and was dean of the School of Music from 2010 to 2015. 